\title{
A prospective study on prevention of contrast - induced nephropathy in Croatia
}

\section{Prospektivno istraživanje prevencije kontrastne nefropatije u Republici Hrvatskoj}

\author{
Ana Vujaklija Brajkovićc ${ }^{1}$, Marija Križić ${ }^{2}$, Jakša Babel ${ }^{1}$, Mia Rora ${ }^{1}$, Radovan Radonić ${ }^{1}$, Ivan Gornik ${ }^{3}$
}

${ }^{1}$ Department of Intensive Care Medicine, University Hospital Centre Zagreb, Zagreb ${ }^{2}$ Department of Oncology, University Hospital Centre Zagreb, Zagreb

${ }^{3}$ Department of Emergency Medicine, University Hospital Centre Zagreb, Zagreb

\section{${ }^{*}$ Corresponding author:}

Ana Vujaklija Brajkovic, M.D. PhD,

research associate

Department of Intensive Care Medicine University Hospital Centre Zagreb

Kispaticeva 12, 10000 Zagreb

e-mail: avujaklija@gmail.com
Abstract. Aim: To explore the protective role of hydration, urine alkalization (Na bicarbonate) and high doses of antioxidant ( $\mathrm{N}$-acetylcysteine) in the prevention of CIN. Material and methods: In a prospective, randomized, single-blinded study patients were divided into three groups: 1) peroral hydration, 2) Na bicarbonate infusion and 3) N-acetylcysteine (NAC) plus $\mathrm{NaHCO} 3$ infusion. Serum creatinine (SCr), blood urea nitrogen (BUN), and neutrophil gelatinase-associated lipocalin (NGAL) were measured before and 48 hours after the angiography. Mehran score was calculated for each patient. Results: The study included 106 patients. Groups were comparable regarding the baseline characteristics. According to Mehran risk score $70 \%$ of patients had a low risk, $24 \%$ medium and $6 \%$ high risk score for development of CIN. After the procedure renal function was preserved in all patients ( $\mathrm{SCr} 103(87.0-121.5)$, BUN 5.8 (4.9-7.6), creatinine clearance 74.7(55.3-97.6), NGAL 11.4(5.4-19.9)) regardless of the Mehran risk score. The follow up was completed for 73 patients (68\%). Twenty two patients (32\%) developed chronic kidney disease, mostly classified as G3a and G3b according to KDIGO guidelines. Chronic kidney disease developed in patients with the positive history of diabetes and in patients who had higher Mehran score before the diagnostic procedure. Conclusion: The study showed that patients with preserved renal function are not prone to CIN. Regardless of the protocol used, no case of CIN was observed. Our results indicate that adequate hydration is a key component in maintaining the renal function. Higher Mehran score might be useful in predicting the development of chronic kidney disease.

Key words: acetylcysteine; contrast media; Croatia; kidney diseases; sodium bicarbonate Trial identification number: ClinicalTrials.gov Identifier: NCT02761577

Sažetak. Cilj: Ispitati protektivnu ulogu hidracije, alkalizacije mokraće (natrijevim bikarbonatom) i visokih doza antioksidansa ( $\mathrm{N}$-acetilcistein) u prevenciji kontrastne nefropatije. Materijali $\boldsymbol{i}$ metode: $U$ prospektivnom istraživanju pacijenti su bili podijeljeni u tri skupine: 1) peroralna hidracija, 2) infuzija natrijevog bikarbonata i 3) infuzija $\mathrm{N}$-acetilcisteina (NAC) i NaHCO3. Serumska vrijednost kreatinina, ureje i neutrophil gelatinase-associated lipocalin (NGAL) izmjerene su prije i 48 sati nakon angiografije. Svakom pacijentu izračunati su Mehran bodovi koji predstavljaju rizik razvoja kontrastne nefropatije. Rezultati: U istraživanje je uključeno 106 pacijenata. Sve tri skupine pacijenata imale su usporedive osnovne karakteristike. Prema bodovima po Mehranu, 70 \% pacijenata imalo je niski rizik, $24 \%$ srednji i 6 \% visoki rizik razvoja kontrastne nefropatije. Nakon kontrastne pretrage bubrežna funkcija bila je očuvana u svih pacijenata (serumski kreatinin 103 (87.0 - 121.5), urea 5.8 (4.9 - 7.6), klirens kreatinina 74.7 (55.3 - 97.6), NGAL $11.4(5.4$ - 19.9)) neovisno o riziku procijenjenom bodovima po Mehranu. Praćenje je završeno za 73 pacijenta (68 \%). Dvadeset i dva pacijenta (32\%) razvila su kroničnu bubrežnu insuficijenciju, klasificiranu prema KDIGO smjernicama kao G3a i G3b. Kronična bubrežna insuficijencija razvila se u pacijenata sa šećernom bolesti i u pacijenata koji su imali viši broj bodova prema Mehranu prije dijagnostičke pretrage. Zaključak: Istraživanje je pokazalo da pacijenti s normalnom bubrežnom funkcijom imaju mali rizik razvoja kontrastne nefropatije. $\mathrm{U}$ ispitivanoj skupini pacijenata nije zabilježen niti jedan slučaj kontrastne nefropatije bez obzira na vrstu protokola koji je korišten za hidraciju. Naši rezultati ukazuju na to da je adekvatna hidracija ključna u prevenciji kontrastne nefropatije. Nadalje, postoji mogućnost da viši broj

http://hrcak.srce.hr/medicina 
bodova po Mehranu može poslužiti kao prediktor razvoja kronične bubrežne bolesti.

Ključne riječi: acetilcistein; bolesti bubrega; kontrastno sredstvo; natrijev bikarbonat; Republika Hrvatska Registar i broj registracije: ClinicalTrials.gov Identifier: NCT02761577

\section{INTRODUCTION}

Contrast-induced nephropathy (CIN) is a common complication of procedures that use contrast media. It is defined as either an absolute $(\geq 0.5 \mathrm{mg} /$ $\mathrm{dL} ; \geq 44 \mu \mathrm{mol} / \mathrm{L}$ ) or relative ( $\geq 25 \%$ ) increase in serum creatinine levels 48-72 hours after exposure to the iodinated contrast media.

Even though there are more than 1662 articles pertaining to the CIN indexed on Pubmed, there is still an ongoing debate about the incidence, influence on hospital morbidity and mortality and treatment/ prevention of CIN. No study concerning $\mathrm{CIN}$ was performed in Croatia.

According to some studies, CIN is the third most common cause of hospital acquired acute renal failure ${ }^{1}$. Other studies showed that CIN is responsible for nearly $10 \%$ of hospital acquired acute renal failure ${ }^{2-4}$. On the other hand, Thomsen et al found that the risk of $\mathrm{CIN}$ is less than $1 \%$ in patients without history of renal disease ${ }^{5}$.

Certain groups of patients are more prone to CIN. Mehran et al made a risk score for the development of $\mathrm{CIN}^{6}$. The risk factors included in the score were hypertension, congestive heart failure, chronic kidney disease, age $>75$ years old, anemia, volume of contrast and need for the use of intra-aortic balloon pump. Patients with a score less than 5 have a $7.5 \%$ risk of $\mathrm{CIN}$ and $0.04 \%$ risk of dialysis, whereas patients with a score greater than 16 have a $57.3 \%$ risk of CIN and $12.6 \%$ risk of dialysis.

As there is no specific treatment for $\mathrm{CIN}$, prevention remains the most effective strategy. Several interventions have been investigated for the prevention of CIN. They are based on the hydration protocols with different solutions and various amount of fluids applied ( $0.9 \%$ sodium chloride, $0.45 \%$ sodium chloride plus $5 \%$ glucose $\left.{ }^{7}\right)$. Also, numerous pharmacologic agents have been investigated in the prevention of $\mathrm{CIN}$, such as sodium bicarbonate (Na bicarbonate) ${ }^{8}$, N-acetylcysteine $(\mathrm{NAC})^{9-12}$, theophylline ${ }^{2}$, simvastatin ${ }^{13}$, atorvasta$\operatorname{tin}^{14}$, nebivolol ${ }^{15}$, and even erythropoietin ${ }^{16}$. The majority of the studies found benefits of hydration with Na bicarbonate and high doses of NAC in prevention of CIN. Administration of nebivolol and atorvastatin showed some benefits in the prevention of CIN, while application of simvastatin and erythropoietin had no effect. However, all these results necessitate further research and standardization of protocols.

Contrast-induced nephropathy (CIN) is a form of kidney injury caused by exposure to iodinated contrast media. $\mathrm{CIN}$ is considered as the third most common cause of hospital acquired acute renal failure. Even though more than 1662 articles referring CIN is indexed on Pubmed no study was conducted in Croatia.

Neutrophil gelatinase-associated lipocalin (NGAL) also known as lipocalin-2 (LCN2) or oncogene $24 p 3$ is a protein that is used as a biomarker of kidney injury. Urinary NGAL is an early marker of acute kidney injury (AKI) in a wide variety of settings $^{17-19}$. Elevated urine NGAL levels are detected within two hours of the kidney insult ${ }^{20}$. Recent studies found NGAL a promising biomarker of CIN after coronary angiography ${ }^{21-22}$ and computed tomography ${ }^{23}$. However, as with hydration protocols there was no uniform time at which urine NGAL was estimated.

Primary goal of this study was to define hydration protocols and to explore the protective role of hydration (peroral and parenteral), urine alkalization (Na bicarbonate) and high doses of antioxidant (NAC) in the prevention of CIN.

\section{MATERIALS AND METHODS}

This was a prospective randomized trial conducted at the University Hospital Centre Zagreb, Croatia. Study included adult patients (older than 18 year) admitted to the medical ward in the period from June 2012 to July 2013. The patients admitted due to angina (stable, unstable), coronary artery disease, cardiomyopathy, valvular disease, vasculitis and peripheral arterial disease were included in the study. 
Exclusion criteria were already known kidney dysfunction, uncontrolled hypertension (systolic blood pressure $>160 \mathrm{~mm} \mathrm{Hg}$ and/or diastolic blood pressure $>100 \mathrm{~mm} \mathrm{Hg}$ ), pregnancy and lactation, the history of allergic reaction to contrast agents, cardiogenic shock, pulmonary edema, multiple myeloma, urgent coronary angiography, receiving contrast agents two days prior to the study and 48 hours within the study, using diuretics, NAC, sodium bicarbonate, theophylline, dopamine, mannitol, metformin, and non-steroidal anti-inflammatory drugs during the study.

Adequate hydration before the intervention is a key component in maintaining the renal function in patients with low risk for development of CIN. After 5 years chronic kidney disease developed in patients with positive history of diabetes and in patients who had higher Mehran score before the diagnostic procedure.

The sample size was estimated to 90 patients taking into account the significance level of 0.05 with the power of $80 \%$.

Patients were randomly assigned to the standard hydration protocol used in our institution (first group - peroral hydration of $1500 \mathrm{ml}$ water on the day of the procedure) and an active prophylactic treatment before angiography (the second group - a bicarbonate infusion; the third group - NAC plus $\mathrm{Na}$ bicarbonate infusion). $\mathrm{Na}$ bicarbonate solution was prepared by adding $150 \mathrm{~mL}$ Na bicarbonate $8.4 \%$ to $850 \mathrm{~mL}$ isotonic normal saline. The second group received $3 \mathrm{~mL} / \mathrm{kg} /$ hour of $\mathrm{Na}$ bicarbonate, an hour prior to angiography and $1 \mathrm{~mL} /$ $\mathrm{kg} /$ hour, within six hours after angiography. The third group received parenteral NAC (1200 mg twice a day) one day before angiography, on the day of the angiography, and one day after the diagnostic procedure in addition to $\mathrm{Na}$ bicarbonate solution on the day of the angiography. In both groups, the maximum dose administered was that administered for patients weighing $100 \mathrm{~kg}$. The low-osmolar iodinated contrast agent was used. CIN was defined as an absolute increase of 0.5 $\mathrm{mg} / \mathrm{dL}$ or a relative increase of $>25 \%$ in creatinine levels 48 hours after the procedure. Serum creatinine, BUN, creatinine clearance and NGAL were measured at the baseline and 48 hours after the diagnostic procedure. All tests were performed in the hospital central laboratory. A chemiluminescent microparticle immunoassay (CMIA) (ARCHITECT analyzer, Abbott Diagnostics) was used for the quantitative determination of NGAL in urine. The expected range was determined to be less than or equal to $131.7 \mathrm{ng} / \mathrm{mL}$.

The follow up was preformed 5 years after the indexed hospitalization. Chronic kidney disease was classified according to KDIGO guidelines (2012) into five categories according to GFR (ml/ min/ $1.73 \mathrm{~m}^{2}$ : G1 Normal or high $\geq 90$, G2 Mildly decreased 60-89, G3a Mildly to moderately decreased 45-59, G3b Moderately to severely decreased 30-44, G4 Severely decreased 15-29 and G5 Kidney failure $<15^{24}$.

\section{Statistics}

Chi-squared test ${ }^{25}$ was used to determine if protocols were comparable regarding all baseline characteristics, except for age where we used the Kruskal-Wallis test ${ }^{26}$. Shapiro-Wilk test ${ }^{27}$ was used to determine whether the data distributions of continuous variables follow the normal distribution. Since most of the data did not follow the normal distribution we used the Kruskal-Wallis test to establish if protocols significantly differ from each other. If the test was statistically significant Conover-Iman test ${ }^{28}$ was used to determine which protocols differ. All tests were conducted in the $\mathrm{R}$ statistical environment ${ }^{29}$ with a probability of type I error of $\alpha=5 \%$. The study protocol was reviewed and approved by the Ethics Committee of the University Hospital Centre Zagreb. All patients included in the study signed an informed consent form. The study was not funded or supported by any organization, group or individual.

\section{RESULTS}

One hundred and six patients were enrolled in the study, 71 (67\%) males and 35 females (33\%). Median age of the patients was 69. There were 37 patients in the first group (control), 40 in the second (NaHCO3 infusion) and 29 in the third group (NAC + NaHCO3 infusion).

The most common diagnosis was angina and coronary angiography the most common diagnostic 
Table 1. Baseline patients' characteristics. Values are medians with interquartile ranges

\begin{tabular}{|c|c|c|c|c|}
\hline Variable & $\begin{array}{l}\text { All patients } \\
(\mathrm{N}=106)\end{array}$ & $\begin{array}{l}\text { Control } \\
(\mathrm{N}=37)\end{array}$ & $\begin{array}{c}\mathrm{NaHCO} 3 \\
(\mathrm{~N}=40)\end{array}$ & $\begin{array}{c}\mathrm{NaHCO}+\mathrm{NAC} \\
(\mathrm{N}=29)\end{array}$ \\
\hline Age (years) & $69(60-75)$ & $68(58-78)$ & $67.5(61-75)$ & 71(61.5-74) \\
\hline Male sex, $\mathrm{n}(\%)$ & $71(67 \%)$ & $21(57 \%)$ & $28(70 \%)$ & $22(76 \%)$ \\
\hline \multicolumn{5}{|l|}{ Diagnosis } \\
\hline Angina (stable, unstable) & 71 & 25 & 30 & 16 \\
\hline Coronary artery disease & 13 & 2 & 4 & 7 \\
\hline Cardiomyopathy & 6 & 4 & 1 & 1 \\
\hline Valvular disease & 10 & 4 & 2 & 4 \\
\hline Other (vasculitis, peripheral arterial disease) & 6 & 2 & 3 & 1 \\
\hline \multicolumn{5}{|l|}{ Diagnostic procedure } \\
\hline Coronary angiography & 98 & 33 & 37 & 28 \\
\hline CT angiography & 6 & 3 & 2 & 1 \\
\hline Peripheral angiography & 2 & 1 & 1 & 0 \\
\hline \multicolumn{5}{|l|}{ Co-morbidities } \\
\hline Hypertension & 93 & 33 & 37 & 28 \\
\hline Diabetes & 28 & 11 & 10 & 7 \\
\hline Hyperlipidemia & 36 & 15 & 12 & 9 \\
\hline $\mathrm{BMI}\left(\mathrm{kg} / \mathrm{m}^{2}\right)$ & $29(25.7-31)$ & $28.1(24-31)$ & $28(25.9-29.8)$ & $30.6(27.1-33)$ \\
\hline
\end{tabular}

CT computed tomography, BMI body mass index

Table 2. Laboratory values at the baseline and after the procedure. Values are medians with interquartile ranges. The results of the Conver-Iman test are shown beside the median and range values. For all groups with the same letter, the difference between them is not statistically significant. If two variables have different letters ( $a$ and $b$ ), they are significantly different.

\begin{tabular}{|c|c|c|c|c|c|c|c|}
\hline Variable & $\begin{array}{l}\text { All patients } \\
(\mathrm{N}=106)\end{array}$ & $\begin{array}{l}\text { Controls } \\
(\mathrm{N}=37)\end{array}$ & & $\begin{array}{c}\mathrm{NaHCO} 3 \\
(\mathrm{~N}=40)\end{array}$ & & $\begin{array}{c}\mathrm{NaHCO}+\mathrm{NAC} \\
(\mathrm{N}=29)\end{array}$ & \\
\hline \multicolumn{8}{|l|}{ Baseline } \\
\hline Serum creatinine $(\mu \mathrm{mol} / \mathrm{mL})$ & $101(88-117.25)$ & $97(89.5-114.25)$ & a & $102(88.5-117.5)$ & a & $104(86.5-130)$ & a \\
\hline BUN (mmol/L) & $6.35(5.1-8.0)$ & $6.6(5.5-7.7)$ & $a b$ & $5.7(4.9-7.3)$ & a & $7.6(6.0-9.7)$ & $b$ \\
\hline Creatinine clearance $(\mathrm{ml} / \mathrm{min})$ & $71.8(54.9-92.5)$ & $69(55.9-90.1)$ & $a$ & $65.1(52.8-91.1)$ & a & $80.3(68.1-97.6)$ & a \\
\hline NGAL (ng/mL) & $8.8(5.5-16.7)$ & $6.9(4.1-14.0)$ & a & $8.4(4.9-13.5)$ & a & $13.7(8.5-28.4)$ & $b$ \\
\hline \multicolumn{8}{|l|}{ Post-procedural } \\
\hline Serum creatinine $(\mu \mathrm{mol} / \mathrm{mL})$ & $103(87.0-121.5)$ & $100(90.0-112.5)$ & a & $106(90.0-123.0)$ & a & $99.0(83.0-127.8)$ & a \\
\hline BUN (mmol/L) & $5.8(4.9-7.6)$ & $6.4(5 .-8.8)$ & a & $5.4(4.9-6.5)$ & $b$ & $5.9(4.3-7.6)$ & $a b$ \\
\hline Creatinine clearance $(\mathrm{ml} / \mathrm{min})$ & 74.7(55.3-97.6) & $75.0(60.5-105-2)$ & a & 75.5(51.6-93.7) & a & $72.1(58.9-94.5)$ & a \\
\hline NGAL (ng/mL) & $11.4(5.4-19.9)$ & 10.6(4.6-19.8) & a & $10.8(4.7-16.1)$ & a & $14.0(8.8-33.8)$ & a \\
\hline \multicolumn{8}{|l|}{ Difference } \\
\hline Serum creatinine $(\mu \mathrm{mol} / \mathrm{mL})$ & $0.0(-5.0-8.0)$ & $1.0(-3.5-8.0)$ & a & $1.5(-4.0-9.0)$ & a & $-2.5(-14-2.0)$ & $b$ \\
\hline BUN (mmol/L) & $0.2(-0.7-1.3)$ & $0.0(-0.8-0.7)$ & a & $0.1(-0.9-0.85)$ & a & $1.9(0.43-2.9)$ & $\mathrm{b}$ \\
\hline Creatinine clearance $(\mathrm{ml} / \mathrm{min})$ & $-2.0(-19.6-17.3)$ & $-7.2(-20.0-26.4)$ & a & $-0.75(-17.9-15.5)$ & a & $2.1(-21.0-16.3)$ & a \\
\hline NGAL (ng/mL) & $0.6(-1.27-4.3)$ & $1.4(-0.2-3.6)$ & $\mathrm{a}$ & $-0.2(-1.4-3-4)$ & a & $1.3(2.3-6.9)$ & a \\
\hline
\end{tabular}

BUN blood urea nitrogen, NGAL neutrophil gelatinase-associated lipocalin

procedure. Hypertension (93 patients from 106), hyperlipidemia (38 patients from 106) and diabetes (28 patients from 106) were the most common co-morbidities. The most used statin was atorvastatin ( 28 patients, $74 \%$ ), followed by simvastatin (7 patients, $18 \%$ ) and rosuvastatin (3 patients, $8 \%)$.
All groups were comparable regarding baseline characteristics $(P>0.05$; Table 1$)$.

According to Mehran risk score for development of CIN, majority of patients had a low risk (75 patients, $70 \%$ ), quarter had medium risk (25 patients, $24 \%$ ) and 6 (6\%) patients had high Mehran risk score. 
At the baseline all patients had normal serum creatinine level, creatinine clearance and NGAL. BUN level significantly differed among bicarbonate and bicarbonate with NAC group. Before the diagnostic procedure, NGAL was significantly higher in the group of the patients that received infusion of bicarbonate and NAC in comparison with the control group $(P=0.01)$ and the bicarbonate group ( $\mathrm{P}=0.03$ ) (Table 2 ).

After the procedure $\mathrm{SCr}$, creatinine clearance and NGAL remained within normal range in all study groups. BUN was lower in all three groups of patients. However, statistical significance was reached only between the control and the bicarbonate group $(P=0.03)$. After the contrast study NGAL levels were higher in comparison with baseline levels in all study groups, however, it did not reach statistical significance. When comparing serum creatinine difference among groups it is notable that patients in the third group had a significant decrease $(-2.5(-14-2.0))$ in comparison with the control group $(P=0.04)$ and with the bicarbonate group $(P=0.02)$.

The follow up was preformed 5 years after the indexed hospitalization. Data were collected for 73 patients (68\%). Twenty two patients (32\%) developed chronic kidney disease, mostly classified as G3a and G3b according to KDIGO guidelines. Chronic kidney disease developed in patients with positive history of diabetes and in patients who had higher Mehran score before the diagnostic procedure.

\section{DISCUSSION}

This study showed that patients with preserved renal function are not prone to CIN. Regardless the protocol used, only peroral hydration, infusion of bicarbonate or infusion of bicarbonate with high dose of NAC, no case of CIN was observed. The results indicate that adequate hydration before the intervention is a key component in maintaining the renal function in patients exposed to the contrast agents. In support of this claim is the fact that patients in the third group had higher levels of BUN and NGAL before the diagnostic procedure, and that after hydration BUN level decreased and NGAL did not rise. In this study we used standard laboratory measures for the evaluation of renal function such as serum creatinine and creatinine clearance along with a novel biomarker of renal injury - NGAL. In previous studies NGAL was determined four hours $^{3-22}$, six hours h $^{23}, 24$ hours $^{3}$ and 48 hours he $^{22}$ after the procedure. Liebetrau et $\mathrm{al}^{3}$ found that NGAL concentration was significantly higher one day after percutaneous coronary intervention $(\mathrm{PCl})$ in the group of patients that developed $\mathrm{CIN}$, and no difference was observed 4 hours after $\mathrm{PCl}$. These results differ from the findings of Padhy et $\mathrm{al}^{22}$ that detected an increase of the serum NGAL $4 \mathrm{~h}$ after the $\mathrm{PCl}$ and a gradual decline to near normal level at $48 \mathrm{~h}$ in CIN cases. Filiopoulos et $\mathrm{al}^{23}$ found a significant elevation of plasma NGAL six hours after the procedure.

Given the fact that CIN is defined as a change in serum creatinine $48-72 \mathrm{~h}$ after the contrast exposure, and that there is no consensus regarding the time of determining the NGAL in the context of CIN, we decided to measure NGAL at the same time as Scr. The results show no increase of NGAL. However, we should take into account that NGAL is an early biomarker of renal injury, so it is possible that NGAL levels would be higher if determined earlier.

According to previous studies hypertension ${ }^{22}$ and hypercholesterolemia, at least in rats $^{30}$, are possible risk factors for development of CIN. Even though hypertension and hyperlipidemia where quite frequent co-morbidities in the studied population, we observed no influence on the incidence of CIN.

Previous studies found a positive effect of certain statins on preservation of renal function during contrast procedures. Even though statins were not a part of a protocol for prevention of CIN, we analyzed the possible effects of those drugs on renal function. We observed no additional positive effect of lipid lowering agents for prevention of $\mathrm{CIN}$, taking into account the low number of patients taking statins and heterogeneity of statins in the studied population.

The follow up was completed for two thirds of patients. Data indicate that patients with higher Mehran score more often develop chronic renal disease. Even though Mehran score is used to predict CIN in the acute setting, we observed that in the follow up renal function remained normal in patients with low Mehran score, and 
majority of patients with high Mehran score (5/6 patients) developed chronic kidney disease. In studied population patients with high Mehran score also had a positive history of diabetes, which is a well known risk factor for development of renal disease. To conclude, it is possible that higher Mehran score could be associated with later development of renal injury but further investigations are needed.

The most important limitation of this study is relatively small number of patients. However, the number is comparable with other studies ${ }^{3-22}$. Results of the study indicate that CIN does not represent an important health problem in population with previously normal renal function.

\section{CONCLUSIONS}

The study showed that patients with preserved renal function are not prone to contrast induced nephropathy. Our results indicate that adequate hydration is a key component in maintaining the renal function. Infusion of sodium bicarbonate or $\mathrm{N}$-acetylcysteine provided no additional benefit on preservation of renal function in the patients with a low risk for the development of contrast induced nephropathy.

Even though Mehran score serves as an acute predictor of contrast induced nephropathy, it could be useful in predicting the development of chronic kidney disease.

Neutrophil gelatinase-associated lipocalin is an early biomarker of kidney injury and its determination is a useful predictor of contrast induced nephropathy, however, there is no uniform protocol defining the period when to determine it.

\section{ACKNOWLEDGEMENTS}

We would like to thank Mladen Ognjenović for his assistance during statistical analysis.

Conflicts of interest statement: the authors report no conflicts of interest.

\section{REFERENCES}

1. Nicola R, Shaqdan KW, Aran K, Mansouri M, Singh A, Abujudeh HH. Contrast-Induced Nephropathy: Identifying the Risks, Choosing the Right Agent, and Reviewing Effective Prevention and Management Methods. Curr Probl Diagn Radiol 2015;44:501-4.
2. Huber W, Eckel F, Hennig M, Rosenbrock H, Wacker A, Saur D et al. Prophylaxis of contrast material-induced nephropathy in patients in intensive care: acetylcysteine, theophylline, or both? A randomized study. Radiology 2006;239:793-804.

3. Liebetrau C, Gaede L, Doerr O, Blumenstein J, Rixe J, Teichert $\mathrm{O}$ et al. Neutrophil gelatinase-associated lipocalin (NGAL) for the early detection of contrast-induced nephropathy after percutaneous coronary intervention. Scand J Clin Lab Invest 2014;74:81-8.

4. McCullough PA, Wolyn R, Rocher LL, Levin RN, O'Neill WW. Acute renal failure after coronary intervention: incidence, risk factors, and relationship to mortality. Am J Med 1997;103:368-75.

5. Thomsen HS, Bush WH. Adverse Effects of Contrast Media. Drug Saf 1998;19:313-24.

6. Mehran R, Aymong ED, Nikolsky E, Lasic Z, lakovou I, Fahy $\mathrm{M}$ et al. A simple risk score for prediction of contrast-induced nephropathy after percutaneous coronary intervention: Development and initial validation. J Am Coll Cardiol 2004;44:1393-9.

7. Mueller C, Buerkle G, Buettner $\mathrm{HJ}$ et al. Prevention of contrast media-associated nephropathy: Randomized comparison of 2 hydration regimens in 1620 patients undergoing coronary angioplasty. Arch Intern Med 2002;162:329-36.

8. Motohiro M, Kamihata H, Tsujimoto S, Seno T, Manabe $\mathrm{K}$, Isono $\mathrm{T}$ et al. A new protocol using sodium bicarbonate for the prevention of contrast-induced nephropathy in patients undergoing coronary angiography. Am J Cardiol 2011;107:1604-8.

9. Koc F, Ozdemir K, Kaya MG, Dogdu O, Vatankulu MA, Ayhan $S$ et al. Intravenous acetylcysteine plus high-dose hydration versus high-dose hydration and standard hydration for the prevention of contrast-induced nephropathy: CASIS -a multicenter prospective controlled trial. Int J Cardiol 2012;155:418-23.

10. Pezeshgi A, Parsamanesh N, Farhood G, Mahmoodi K. Evaluation of the protective effect of $\mathrm{N}$-acetylcysteine on contrast media nephropathy. J Renal Inj Prev 2015; 4:109-12.

11. Recio-Mayoral A, Chaparro M, Prado B, Cózar R, Méndez I, Banerjee D et al. The Reno-Protective Effect of Hydration With Sodium Bicarbonate Plus N-Acetylcysteine in Patients Undergoing Emergency Percutaneous Coronary Intervention. The RENO Study. J Am Coll Cardiol 2007;49:1283-8.

12. Trivedi H, Daram S, Szabo A, Bartorelli AL, Marenzi G. High-dose $\mathrm{N}$-acetylcysteine for the Prevention of Contrastinduced Nephropathy. Am J Med 2009;122:874.e9-15.

13. Jo S-H, Koo B-K, Park J-S, Kang H-J, Cho Y-S, Kim Y-J et al. Prevention of radiocontrast medium;induced nephropathy using short-term high-dose simvastatin in patients with renal insufficiency undergoing coronary angiography (PROMISS) trial;a randomized controlled study. Am Heart J 2008;155:499e1-8.

14. Fu M, Dai W, Ye Y, Lu Q, He W. High Dose of Atorvastatin for the Treatment of Contrast-Induced Nephropathy After Carotid Artery Stenting. Am J Ther 2017;24:e718-22.

15. Thamcharoen N, Thongprayoon C, Edmonds PJ, Cheungpasitporn W. Periprocedural Nebivolol for the Prevention of Contrast-Induced Acute Kidney Injury: A Systematic Review and Meta-analysis. N Am J Med Sci 2015;7:446-51. 
16. Shema-Didi L, Kristal B, Eizenberg S, Marzuq N, Sussan $M$, Feldman-Idov $Y$ et al. Prevention of contrast-induced nephropathy with single bolus erythropoietin in patients with diabetic kidney disease: A randomized controlled trial. Nephrology 2015;21:295-300.

17. Mishra J, Dent $C$, Tarabishi R, Mitsnefes MM, Ma $Q$, Kelly $C$ et al. Neutrophil gelatinase-associated lipocalin (NGAL) as a biomarker for acute renal injury after cardiac surgery. Lancet 2005;365:1231-8.

18. Mori K, Nakao K. Neutrophil gelatinase-associated lipocalin as the real-time indicator of active kidney damage. Kidney Int 2007;71:967-70.

19. Nickolas TL, O'Rourke MJ, Yang J, Sise ME, Canetta PA, Barasch $\mathrm{N}$ et al. Sensitivity and specificity of a single emergency department measurement of urinary neutrophil gelatinase-associated lipocalin for diagnosing acute kidney injury. Ann Intern Med 2008;148:810-9.

20. Bennett M, Dent $C L, M a ~ Q$, Dastrala S, Grenier F, Workman $R$ et al. Urine NGAL Predicts Severity of Acute Kidney Injury After Cardiac Surgery: A Prospective Study. Clin J Am Soc Nephrol 2008;3:665-73.

21. Bachorzewska-Gajewska H, Malyszko J, Sitniewska E, Malyszko JS, Pawlak K, Mysliwiec M et al. Could Neutrophil-Gelatinase-Associated Lipocalin and Cystatin C Predict the Development of Contrast-Induced Nephropathy after Percutaneous Coronary Interventions in Patients with Stable Angina and Normal Serum Creatinine Values? Kidney Blood Press Res 2007;30:408-15.

22. Padhy M, Kaushik S, Girish MP, Mohapatra S, Shah S, Koner BC. Serum neutrophil gelatinase associated lipocalin (NGAL) and cystatin $C$ as early predictors of contrast-induced acute kidney injury in patients undergoing percutaneous coronary intervention. Clin Chim Acta 2014;435:48-52.

23. Filiopoulos V, Biblaki D, Vlassopoulos D. Neutrophil gelatinase-associated lipocalin (NGAL): a promising biomarker of contrast-induced nephropathy after computed tomography. Ren Fail 2014;36:979-86.

24. Stevens PE, Levin A, for the Kidney Disease: Improving Global Outcomes Chronic Kidney Disease Guideline Development Work Group M. Evaluation and management of chronic kidney disease: Synopsis of the kidney disease: improving global outcomes 2012 clinical practice guideline. Ann Intern Med 2013;158:825-30.

25. Hollander M, Wolfe DA, Chicken E. Comparing Two Success Probabilities. In: Hollander M, Wolfe DA, Chicken E (eds). Nonparametric Statistical Methods. New Jersey: John Wiley \& Sons, Inc., 2014;495-534.

26. Hollander M, Wolfe DA, Chicken E. The One-Way Layout. In: Hollander M, Wolfe DA, Chicken E (eds). Nonparametric Statistical Methods. New Jersey: John Wiley \& Sons, Inc., 2014;202-88.

27. Shapiro SS, Wilk MB. An Analysis of Variance Test for Normality (Complete Samples). Biometrika 1965;591-611.

28. Conover W, Iman RL. On multiple-comparisons procedures. Informal Report. Los Alamos, New Mexico: University of California, Los Alamos Scientific Laboratory, 1979.

29. R Core Team. A language and environment for statistical computing. Vienna, Austria: R Foundation for Statistical Computing, 2016.

30. Yang D, Lin S, Yang D, Wei L, Shang W. Effects of shortand long-term hypercholesterolemia on contrast-induced acute kidney injury. Am J Nephrol 2012;35:80-9. 